\title{
The Influence of Boiling on Decreasing Levels of Heavy Metal (Zn) in Catfish From Ganet Landfills Fishpond in Tanjung Pinang City 2016
}

\author{
Veronika Amelia Simbolon ${ }^{1}$, Winanda Putri ${ }^{2}$, Erpina Santi Meliana Nadeak ${ }^{3}$, Nurhayani Lubis ${ }^{4}$ \\ ${ }^{1,4}$ Universitas Sumatera Utara, Indonesia \\ veronikaameliasimbolon@gmail.com \\ yanie_moredyahoo.com \\ ${ }^{2,3}$ Poltekkes Kemenkes Tanjungpinang, Indonesia \\ winandaputeri@gmail.com \\ santi_deaks@yahoo.co.id
}

\begin{abstract}
Leachate collection tub on environmentally protective facility of Ganet lanfills is leak. It causing leachate seepage and contaminating around of fishpond in Ganet landfills with heavy metals such as $\mathrm{Pb}, \mathrm{Cu}$, and $\mathrm{Zn}$. This heavy metals acumulation will causing health problems for aquatic biota. This study result is to knowing the influences of boiling process on decreasing level of Zinc contained in catfish.

This is a pre- experiment study using One Group Pretest and Postest research design. This study using Purposive Sampling as sampling methods. Sampling point is taken in two area thats is nearest point and farthest point from source of pollution. Analysis of heavy metals content on catfish is using Atomic Absorption Spectrophotometer (AAS).

There are $104,75 \mathrm{mg} / \mathrm{kg} \mathrm{Zn}$ content in catfish from nearest point $(50 \mathrm{~m})$ before boiling process. This amount is exceed from allowed standard from Direktorat Jenderal Pengawasan Obat dan Makanan Number : 03725/B /SK/VII/89 which only allowed $100 \mathrm{mg} / \mathrm{kg}$. After boiling proces, the level of $\mathrm{Zn}$ content is decrease into1,14 mg/l $(45,75 \%$.). The result of farthest point is known not exceed from allowed standards.

This heavy metals different test conclusion showing there is a sygnificant differences of content of $\mathrm{Zn}$ in catfish with boiling process and catfish without boiling process.Catfish from pondfish is safe for consumption afer boiling process.
\end{abstract}

Keywords- Catfish, Zink, Heavy Metals, Boiling, Landfill

\section{INTRODUCTION}

Heavy metals contents by bioaccumulation and biomagnification process on food can be detect The amount of absorbed and distributed of heavy metals on fish is depend on compound, concentrate of pollutant, miroorganism activity, sediment texture, species and element of fish whisch live in that environment [12].
Catfish is a kind of fish that is the most commonly eaten by people and children. Delicious taste, high nutrition, cheap price and also easy to cultivation. Nutrient composition in cat fish are protein $(17,7 \%)$, fat $(4,8 \%)$, mineral $(1,2 \%)$, and water $(76 \%)$ [3]

Catfish is a kind of very adaptable fish with stagnant water environment and in water flow environment in their adult age [8]

Garbages is really related with public health, garbages is a source of various kind of microorganism that will produce phatogens bacterium and also various kind of insect as disease vectors. That is a answer why gabages have to through a long and complete garbage management to prevent peoples from garbage disturbance and disease threats. A good waste management is not only goog for health but also good to environment. Waste management process including collecting, garbage trasnport until the extermination step is waste management step to keep peoples health and living environment [10].

One of alternative of waste management is to make a sanitary landfill as treatment for garbage. Sanitary landfill is an activity taking out the trash everyday to a certain place and then this place will be closed at the end of the processing. This process will occur everyday accordance to the capacity of the certain place of landfills. This Sanitary landfill methods will causing problems if not implemented properly. The most coomon impact is leachate contamination, that 
isingress of fluid from the process of decomposition of organic processinto soil. Another impact could happen is methane $\left(\mathrm{CH}_{4}\right)$ and Hidrogen sulfide $\left(\mathrm{H}_{2} \mathrm{~S}\right)$ gas migration that comes from anaerobic organics decomposition. [10].

In normal condition, leachate water could be find on the bottom of landfilld, it will flow into the subsoil. Even lateral flow could happen, this flow is depend on the caractheristics of surounding materials. The importance of the leachate flow direction (vertical flow) and its related with groudwater contamination makes this problem is more focused on vertical flow seepage. It needs to be known, the velocity of leachate seepage that is velocity of leachate from landfills bottom to the ground water on aquifer surface that move to bedrock aquifer is also need to to be considered [5].

The leakage on leachate collection tub around Ganet lanfills [1]. In this area, there is a river that flow to the area of catfish pond owned by resident.There are several heavy metals contamintation in these catfish pond such as $\mathrm{Pb}, \mathrm{Cu}$, and $\mathrm{Zn}$. area. This study showed the highest contamination from heavy metals in those catfish pond is come from $\mathrm{Zn} . \mathrm{Zn}$ previous testfrom fish flesh showed $2.44 \mathrm{mg} / \mathrm{l}$ orequal to $122 \mathrm{mg} / \mathrm{kg}$. This result is more high than maximum limit fromquality standard of food. Maximum limit of Zinc (Zn)on food according to Direktur Jenderal Pengawasan Obat dan Makanan Nomor: 03725/B/SK/VII/1989 is $100 \mathrm{mg} / \mathrm{kg}$. Catfish production from those pond fish is distributed to several markets in Tanjung Pinang City [5].

Sample could be treat in various way such as fried, grilled and boiled. Fried and grilled process could increase metal content in flesh, while boiledcould decrease metal content in food [6].

Boiling process taken 15 minutes in temperature $100^{\circ} \mathrm{C}$ so the flesh is in really cooked condition, [11]. This research purposed is to knowing "The of Influence of Boiling on Deccreasing Levels of Heavy Metal $(\mathrm{Zn})$ in Catfish From Ganet Landfills Fishpond"

Zinc is a natural component that could be found in earths's crust. Zinc has reactive caractheristics, bluish white, faded in vapor condition, and burnt and flame in air condition with light green flame. Zinc can react with acid, alkali and non metal compounds. $\mathrm{Zn}$ has an atomic number 30 and hasmelting point in $419,73^{\circ} \mathrm{C}$. Source of $\mathrm{Zn}$ is $\mathrm{Zn}$ osphalerit (sulfide), smithsonit (carbonic), calamine (silicate), dan franklinit (Zn, Mn Fe-okside).

There are 370 metrik ton/year $\mathrm{Zn}$ metals that contaminated sea from geology process while there are 3.430 metrik ton/ year $\mathrm{Zn}$ from human activity in nature. Zinc nornaly found in association with other base metals, or mineral that containing $\mathrm{Zn}$ in nature such as calamine, franklinite, smithsonit, willenit dan zinkil. The abundance of $\mathrm{Zn}$ this world make it to be $27^{\text {th }}$ as constituent of the erth's crust. [13].

Actualy, $\mathrm{Zn}$ is a non-toxic element, but it will be very toxic in ion condition Zinc shakesorzinc chillsis causing by $\mathrm{Zn}$-okside inhalation during galvanization process or grafting material using $\mathrm{Zn}$. $\mathrm{Zn}$ is an essential element in human body but in high doses it will extremely toxic. Excessive absoption of $\mathrm{Zn}$ could depressCo and $\mathrm{Fe}$. $\mathrm{Zn}$ high exposure is really rare happend $\mathrm{Zn} . \mathrm{Zn}$ does not accmulated during exposure time because it does not accumulated in homeostatic mechanism. Mean while excessive of $\mathrm{Zn}$ will be absorbed and it will be saved in liver [13].

\section{METHODOLOGY}

Sampling is taken in two point [1] where taken in nearest pond fish $(50 \mathrm{~m})$ and fathest pond fish $(250 \mathrm{~m})$ from leaky leachate collection tub Sampling tehnics that used is purposive sampling. This study is a preexperimen twith One Group Pretest and Postest design. Previously, writer had observed the location so writer could testing change that could happen after treatment [9]. This study located in Ganet street KM 11 Tanjung Pinang Subdistrict. Laboratorium Ilmu Kelautan dan Perikanan UMRAH and BTKL PP Kelas 1 Batam. After knowing the amount of $(\mathrm{Zn})$ before and after boiling process, the next step is doing Paired $T$ test.

After cleaning the catsfish sample, samples are boiled in \pm 15 minutes with comparison flesh and water (1:1). Then drained the flesh and chopped into mini 
size and weigh the meat into 1 gram. Take 1 gram of meat and bake in oven to make it dry in temperature $105^{\circ} \mathrm{C}$ for 24 hour. Then colled the flesh in desikator and add $10 \mathrm{ml} \mathrm{HNO}_{3}$ fluid then heat it on the hot plate for 2-3 hour until it change to be trasnparant clear. Add this fluid with $25 \mathrm{ml}$ of aquadesand filtrate, this filtrat solution will be poured into the sample botle and analyzed using Atomic Absorption Spectrophotometer $(A A S)$ system.

\section{RESULT AND DISCUSSION}

Sampling was taken in Thursday $5^{\text {th }}$ May 2016 from two fishpond from nearest point $(50 \mathrm{~m})$ and farthest point $(250 \mathrm{~m})$. Temperature of water from fish pond is $28^{\circ} \mathrm{C}$ with $\mathrm{pH} 7$ in that time.7. Result of Zinc test analysis from sample can be seen in table below :

TABLE I

THE CONTENT OF (ZN)

\begin{tabular}{|c|c|c|c|c|c|c|c|c|c|}
\hline \multirow{2}{*}{ No } & \multirow{2}{*}{$\begin{array}{l}\text { Distance } \\
\text { (m) }\end{array}$} & \multicolumn{3}{|c|}{ Pretest (mg/l) } & \multicolumn{3}{|c|}{ Post test(mg/l) } & \multirow{2}{*}{$\begin{array}{c}\text { Decreasing of } \mathbf{Z n} \\
(\%)\end{array}$} & \multirow{2}{*}{ Note } \\
\hline & & $\mathbf{I}$ & II & Average & I & II & Average & & \\
\hline 1 & 50 & 2.30 & 1.89 & 2.095 & 1.16 & 1.12 & 1.14 & 45.6 & - \\
\hline 2 & 250 & 1.29 & 1.11 & 1.2 & 1.14 & 1.04 & 1.09 & 9.17 & - \\
\hline
\end{tabular}

TABLE II

ZINC (ZN) CONVERSION RESULT

\begin{tabular}{|c|c|c|c|c|c|c|c|c|}
\hline \multirow[b]{2}{*}{$\begin{array}{l}\mathbf{N} \\
\mathbf{0}\end{array}$} & \multirow[b]{2}{*}{$\begin{array}{c}\text { Distance } \\
\text { (m) }\end{array}$} & \multicolumn{2}{|c|}{ Pre Test } & \multicolumn{2}{|c|}{ Post Test } & \multirow{2}{*}{\begin{tabular}{|c|} 
Quality \\
Standard \\
(Dirjen BPOM \\
03725/SK/VII/ \\
1989) \\
\end{tabular}} & \multicolumn{2}{|c|}{ Ket } \\
\hline & & $\begin{array}{c}\text { Aver } \\
\text { age } \\
(\mathrm{mg} / \mathrm{l})\end{array}$ & \begin{tabular}{|c} 
After \\
Convert \\
ion \\
$(\mathbf{m g} / \mathbf{k g})$ \\
\end{tabular} & $\begin{array}{c}\text { Average } \\
\text { (mg/l) }\end{array}$ & $\begin{array}{c}\text { After } \\
\text { Conver } \\
\text { tion } \\
(\mathbf{m g} / \mathbf{k g})\end{array}$ & & \begin{tabular}{|l} 
Pre \\
Test
\end{tabular} & $\begin{array}{l}\text { Post } \\
\text { Test }\end{array}$ \\
\hline 1 & 50 & 2.095 & 104.75 & 1.14 & 57 & \multirow{2}{*}{$100 \mathrm{mg} / \mathrm{kg}$} & $\begin{array}{c}\text { exccee } \\
\mathrm{d}\end{array}$ & exceed \\
\hline 2 & 250 & 1.2 & 60 & 1.09 & 54.5 & & \begin{tabular}{|c|} 
Not \\
excee \\
d \\
\end{tabular} & \begin{tabular}{|c|} 
Not \\
exceed \\
Ba \\
\end{tabular} \\
\hline
\end{tabular}

(Source: Analysis result from BTKL PP Kelas I Batam)

Before boiling process, the content of Zinc in cat fish samples after conversion at the nearest point $(50 \mathrm{~m})$ is $104,75 \mathrm{mg} / \mathrm{kg}$ and the content of Zinc in catfish samples at farthest point $(250 \mathrm{~m})$ is $60 \mathrm{mg} / \mathrm{kg}$. After boiling process, the content of Zinc after conversion is decrease into $57 \mathrm{mg} / \mathrm{kg}$ at the nearest point $(50 \mathrm{~m})$ and $54,5 \mathrm{mg} / \mathrm{kg}$ at the farthest point $(250$ $\mathrm{m})$. The content of Zinc in these samples at the nearest point $(50 \mathrm{~m})$ 104,75 $\mathrm{mg} / \mathrm{kg}$ are exceed fromthe quality.
It is happen because there is a leakage in leachate collection tub. These leacthe flow into river. This result is similiar with previous study that showed of Zinc $(\mathrm{Zn})$ heavy metals on fishpond water at the Ganet landfills [1].

These result are exceed from allowed standard refers to quality standard of Direktorat Jenderal Pengawasan Obat dan Makanan Nomor:03725/B /SK/VII/89 with $\mathrm{Zn}$ amount $100 \mathrm{mg} / \mathrm{kg}$, in a long period, peoples who eats food that containing $\mathrm{Zn}$ will have a big risk to have a health problem because it will causing mineral deficiencysuch as $\mathrm{Cu}$ and $\mathrm{Fe}$ and in short period, it will causing nausea and vomit [13].

After boiling process, the samples was analyzed by using Atomic Absorption Spectrophotometer (AAS), decreasing of $(\mathrm{Zn})$ heavy metals at nearest point after boiling process is $9,17 \%$ and decreasing of $\mathrm{Zn}$ heavy metals at farthest point is $45,6 \%$.

This process allegedly is an eficient methods to decreasing the content of heavy metals by using heating process. Partly content of $\mathrm{Zn}$ in catfish flesh is dissolved with water by using boling process [6].

The decreasing of $\mathrm{Zn}$ heavy metals in catfish happened beacuse of boiling process. Boiling is a cooking process using boiling water in temperature $100^{\circ} \mathrm{C}$, there will be quick evaporation. Boiling has three steps, that is nucleate, transition and film boiling [7]. Cooking with boiling process has several advantages and weakness. The advantages of using boiling as cooked methods; food is more easy to digested, simple to operate, it will exterminate all pathogens in food and could decreasing heavy metals content, especially fish. But, this process has a weakness too. Boiling process, in very high temperature, could be decreasing several vitamins, proteins, and other nutrients so it will make food become less nutrient and does not looks good in over cooked condition [7].

Boiling process is aims to decrease the level of Zinc in catfish from ganet landfills pondfish. This process using high temperature $100^{\circ} \mathrm{C}$ for 15 minutes. 15 minutes boliling process is a best duration to boiling fish [11]. This condition will makes the fish more tender. Boiling duration in 10 minutes or 20 minutes is 
not proper duration to cook. Flesh will still raw or overcooked. Rear tail bone of fish is easly to be part and easily to crumble [11].

Boiling process would decrease heavy metals content with heating process, this process also helps to cut sulfhydryl and hydroxyl bond in metal compound, Skjodebrand in Dwiloka (2006), said that boiling process would change, chemistry and physics bond of compound condition and others minerals.

\section{ZINC (ZN) CONTENT ANALYSIS TEST}

Paired $\mathrm{T}$ testis a kind of differences test that useful to knowing the level of heavy metals $(\mathrm{Zn})$ in before and after boiling process in catfish. Test result showed, in catfish samples there's a significant differences with p-value 0,045 or $<0,05$ with $\mathrm{H}_{0}$ not acceptable, it means "there is a significant differences of content of $\mathrm{Zn}$ in catfish sample in before and after boiling process.

\section{CONCLUSION}

Based on result and discussion of this study it can be concluded that Zinc content in catfish flesh in nearest point is exceed more than quality standard but it will decrease about 45, 6\% after boiling process and allowed to be eat after boiling process in 15 minutes.

\section{REFERENCES}

[1] Aldo, N, Nadeak, MSE, and Erda Z, "Analisis Kandungan Logam Pb, Cd, $\mathrm{Cu}$, Zn Pada Air Tambak Pada Berbagai Jarak di Sekitar Tempat Pembuangan Akhir (TPA) Ganet Kota Tanjungpinang", Jurnal Poltekkes Jambi, ISSN : 2085-1677, vol 12, pp 1-5, 2014

[2] Ali, M Rembesan Air Lindi (Leachate) Dampak Pada Tanaman Pangan dan Kesehatan. Surabaya, UPN "Veteran” Jawa Timur 2001.

[3] Astawan, M. (2008). Lele bantu pertumbuhan janin. [Online]. Available: http://wilystra2007.multiply.com/journal/item/62/

[4] Depkes RI, 1989. Direktorat Jenderal Pengawasan Obat Dan Makanan No.03725/B/SK/VII/89. Batas Maksimum Cemaran Logamdalam Makanan.

[5] DKPP. Profil Tempat Pemrosesan Akhir (TPA) Ganet Kota Tanjungpinang. Tanjungpinang : 2015

[6] Hikmawati, A dan Sulistyorini. L. Perubahan Kadar Merkuri (Hg) Pada IkanTongkol (Euthynnus,sp) dengan Perlakuan Perendaman Larutan Jeruk Nipis dan Pemasakan.Airlangga University, Surabaya : 2006

[7] Mulyatiningsih, E. Teknik - Teknik Dasar Memasak. FakultasTeknik Universitas Negeri Yogyakarta: 2007

[8] Puspowardoyo, H dan A. Djarijah. 2002. Pembenihan dan Pembesaran LeleDumbo Hemat Air. Kanisius. Yogyakarta

[9] Riyanto, Agus. Aplikasi Metodologi Penelitian Kesehatan. Nuha Medika.Yogyakarta : 2011

[10] Soma, S. 2010. Pengantar Ilmu Teknik Lingkungan, Seri: Pengelola Sampah Perkotaan. Bogor IPB Press
[11] Sumiati, T. Pengaruh Pengolahan Terhadap Mutu Cerna Protein IkanMujair (Tilapia Mossambica). Fakultas Teknologi Pertanian IPB. Bogor: 2008

[12] Supriyanto, C, Samin and Z. Kamal. Analisis Cemaran Logam Berat Pb, $\mathrm{Cu}$, dan $\mathrm{Cd}$ pada Ikan Air Tawar dengan Metode Spektrometri Nyala Serapan Atom (SSA). Seminar Nasional III, Yogyakarta: SDM Teknologi Nuklir, 2007.

[13] Widowati, W. Sastiono A.Rumampuk RJ. Efek Toksik Logam, Pencegahandan Penanggulangan Pencemaran. Penerbit: Andi, Yogyakarta: 2008

[14] Yudha, I. G. 2009. Kajian Logam Berat $\mathrm{Pb}, \mathrm{Cu}, \mathrm{Hg}$ dan $\mathrm{Cd}$ yang Terkandungpada Beberapa Jenis Ikan di Wilayah Pesisir Kota Bandar Lampung. Seminar Hasil Penelitian dan Pengabdian kepada Masyarakat, Unila.Lampung.

[15] Zaki. (2009). Budi Daya Ikan Lele ( Clarias batrachus ). [Online]. Available : http://wilystra2008. biologi.com/journal/item/54/ 